\title{
THE
}

\section{Notes on the marine algae of the Bermudas. 15. Dichotomaria huismanii (Galaxauraceae, Rhodophyta), a new species in the $D$. marginata complex from the western Atlantic}

Craig W. Schneider

Thea R. Popolizio

University of Rhode Island

Dylan S. Spagnuolo

Christopher E. Lane

University of Rhode Island, clane@uri.edu

Follow this and additional works at: https://digitalcommons.uri.edu/bio_facpubs

Terms of Use

All rights reserved under copyright.

\section{Citation/Publisher Attribution}

Schneider, C., Popolizio, T., Spagnuolo, D., et al. (2016). Notes on the marine algae of the Bermudas. 15. Dichotomaria huismanii (Galaxauraceae, Rhodophyta), a new species in the D. marginata complex from the western Atlantic. Botanica Marina, 59(1), pp. 13-29. Retrieved 13 Feb. 2019, from doi:10.1515/ bot-2015-0068

Available at: https://doi.org/10.1515/bot-2015-0068

This Article is brought to you for free and open access by the Biological Sciences at DigitalCommons@URI. It has been accepted for inclusion in Biological Sciences Faculty Publications by an authorized administrator of DigitalCommons@URI. For more information, please contact digitalcommons-group@uri.edu. 
Craig W. Schneider*, Thea R. Popolizio, Dylan S. Spagnuolo and Christopher E. Lane

\section{Notes on the marine algae of the Bermudas. 15. Dichotomaria huismanii (Galaxauraceae, Rhodophyta), a new species in the $D$. marginata complex from the western Atlantic}

DOI 10.1515/bot-2015-0068

Received 19 August, 2015; accepted 7 January, 2016; online first 4 February, 2016

\begin{abstract}
Using plastid-encoded $r b c \mathrm{~L}$ and mitochondrial COI-5P sequence data, the species in Bermuda formerly recognized as Dichotomaria marginata was found to be a cryptic species in a wide complex of species all falling under the morphologically broad species concept for this supposed pantropical species. The new species, Dichotomaria huismanii, shows subtle anatomical and morphological differences when compared to D. marginata, and at present is only known from Bermuda. Bermuda specimens were compared with our isolates of $D$. marginata from St. Croix (Virgin Is.), as well as $r b c$ L sequenced specimens with those from Guadeloupe and Puerto Rico in GenBank as D. marginata. Morphological and molecular characterization of $D$. marginata is provided along with the new species.
\end{abstract}

Keywords: Bermuda; COI-5P; Dichotomaria; D. huismanii sp. nov.; D. marginata; Galaxauraceae; rbcL; Rhodophyta.

\section{Introduction}

In a circumscription of the nemalialean genus Galaxaura, Papenfuss et al. (1982) taxonomically linked many earlier described pairs of species as heteromorphic sporophyte and gametophyte generations of the same species. Subsequently, Huisman et al. (2004) used LSU rDNA sequences to show that Galaxaura was polyphyletic, moving a clade of species to the newly resurrected

*Corresponding author: Craig W. Schneider, Department of Biology, Trinity College, Hartford, CT 06106, USA, e-mail: cschneid@trincoll.edu Thea R. Popolizio and Christopher E. Lane: Department of Biological Sciences, University of Rhode Island, Kingston, RI 02881, USA Dylan S. Spagnuolo: Department of Biology, Trinity College, Hartford, CT 06106, USA genus Dichotomaria. Along with four others, they reassigned two species originally included by Lamarck (1816) in his new genus Dichotomaria, Dichotomaria marginata (J. Ellis et Solander) Lamarck and Dichotomaria obtusata (J. Ellis et Solander) Lamarck, species known during the 20th century as Galaxaura, both being widely reported in the western Atlantic as well as other seas. Pantropical D. obtusata has been shown to be a complex of species, but authentic material from the West Indies has not been sequenced and compared with the various genetic species now known from distant seas (Wiriyadamrikul et al. 2014). Bermuda specimens designated as D. obtusata var. major W.R. Taylor (Taylor 1960) were based on the larger habits they displayed in the islands as compared to the nominate variety, and sequences we have generated from recent collections match those derived from isotype material of D. obtusata var. major by Wiriyadamrikul et al. (2014). Whether they are representative of the species remains to be seen, as material of $D$. obtusata from the region of the type locality (Bahamas Is.) needs to be collected and sequenced for comparison.

The second species presently known from Bermuda, Dichotomaria marginata, is likewise considered pantropical (Papenfuss et al. 1982, Kurihara and Huisman 2006, Guiry and Guiry 2015) and, until recently, has been an easily recognizable member of the genus due to its flattened axes with thickened margins. First described in the genus Corallina from the Bahamas by Ellis and Solander (1786), Corallina marginata J. Ellis et Solander was later moved as the generitype to Dichotomaria by Lamarck (1816), and subsequently into other genera of the Galaxauraceae over its long taxonomic history. When Huisman et al. (2004) analyzed their molecular and anatomical results, they discovered that there were at least three distinct genetic species at the time known as $D$. marginata from Puerto Rico, eastern Africa and Australia. As the type specimen from the Bahamas was apparently lost over the two and a half centuries since its collection, the Ellis and Solander illustration of C. marginata (1786, pl. 22 figure 6) was lectotypified by Papenfuss et al. (1982, footnote 3), 
thus disallowing an anatomical comparison of the genetic species with the morphological type from the western Atlantic Ocean. Nevertheless, Huisman et al. (2004) suggested that the material from Puerto Rico most reasonably would be the best fit for the species given its proximity to the type locality just over $500 \mathrm{~km}$ to its northwest in the Atlantic. For the other two genetic species, Huisman et al. (2004) resurrected synonyms of $D$. marginata as independent species with flattened axes from the IndoPacific region, D. australis (Sonder) Huisman, J.T. Harper et G.W. Saunders (type locality=Victoria, Australia) and D. tenera (Kjellman) Huisman, J.T. Harper et G.W. Saunders (type locality=Mobasa, Kenya). These two, therefore, represented the first segregate species recognized in what had been a morphologically variable and pantropical D. marginata complex outlined by Papenfuss et al. (1982). A second Australian species, D. spathulata (Kjellman) A. Kurihara et Huisman (type locality=Fremantle, Western Australia), was later resurrected from the complex by Kurihara and Huisman (2006), and they suggested additional species might be segregated from $D$. marginata in the future. Interestingly, when Kurihara and Huisman (2006) segregated D. spathulata, they left specimens from the northern tropical region as representatives of $D$. marginata from Australia based on morphological evidence. Lacking $r b c \mathrm{~L}$ sequences for these, this action awaits molecular evidence and analysis for confirmation.

Dichotomaria marginata was first reported as part of the Bermuda flora with its inclusion in the widely disseminated exsiccata Phycotheca Boreali-Americana (P.B.-A) as Brachycladia marginata (J. Ellis et Solander) F. Schmitz (Collins et al. 1913, no. 1930). This early collection was cited by Collins and Hervey (1917) and Howe (1918a) as Galaxaura marginata (J. Ellis et Solander) J.V. Lamouroux, and all subsequent reports in Bermuda followed their lead (see Schneider 2003). In the present study, we have made several recent collections of $D$. marginata in Bermuda and St. Croix, Virgin Is., to compare genetically with other species in the complex, in particular specimens attributed to this species from Puerto Rico analyzed by Huisman et al. (2004) and Guadeloupe by Wang et al. (2005) and Wiriyadamrikul et al. (2014).

\section{Materials and methods}

\section{Standard methods}

Offshore collections from Bermuda and St. Croix, Virgin Is. were made using SCUBA, with site locations marked with a Garmin ${ }^{\mathrm{TM}}$ eTrex H (Olathe, KS, USA). Small portions of each specimen were dried on silica gel for DNA extraction and other samples were preserved in 4-5\% formalin in seawater for sectioning, the remainder being pressed onto herbarium paper as a permanent voucher. Liquid preserved samples were decalcified in $8 \% \mathrm{HCl}$, sectioned with a model 880 American Optical freezing microtome (San Diego, CA, USA), with sections mounted in 30\% corn syrup with acidified $1 \%$ aniline blue in a ratio of 20:1 with a few drops of formalin as a medium preservative. Live specimens chosen for DNA analysis were photographed using a Canon Powershot s90 digital camera (Canon Inc., Tokyo, Japan) and dried herbarium specimens were scanned on an HP 309a Photosmart Premium scanner (Hewlett-Packard Company, Palo Alto, CA, USA). Photomicrographs were taken using Zeiss Axioskop 40 microscope (Carl Zeiss, Oberkochen, Germany) equipped with a model 11.2 Spot InSight 2 digital camera (Diagnostic Instruments, Sterling Heights, MI, USA). The digital images were composed in Adobe Photoshop ${ }^{\mathrm{TM}} \mathrm{CS} 6$ v. 13.0.1 (Adobe Systems, San Jose, CA, USA). Voucher specimens of some numbers are deposited in MICH, NY, the Bermuda Natural History Museum and CWS's personal herbarium, the holotype in the first. Herbarium abbreviations follow the online Index Herbariorum (http://sweetgum.nybg.org/ih/) and standard author initials were taken from Brummitt and Powell (1992).

\section{Molecular methods}

Silica dried samples for DNA analysis were ground in liquid nitrogen and stored at $-20^{\circ} \mathrm{C}$. DNA was extracted from 0.1-0.5 $\mu \mathrm{l}$ ground material using the Sigma-Aldrich (St. Louis, MO, USA) GenElute Plant Genomic Miniprep Kit according to the manufacturer's protocol, with $500 \mu \mathrm{l}$ of modified lysis solution ( $50 \mu \mathrm{l} 10 \%$ TWEEN 20 and $5 \mu \mathrm{l}$ of $20 \mathrm{mg} \mathrm{ml}^{-1}$ ProK), as well as $1 \mathrm{~h}$ of incubation at $23^{\circ} \mathrm{C}$ followed by 20 min on ice (Saunders and Druehl 1993).

DNA was amplified via polymerase chain reaction (PCR) with the Takara Ex-Taq DNA polymerase kit (PanVera, Madison, WI, USA) in an Eppendorf AG Mastercycler epGradient thermal cycler (Eppendorf, Hamburg, Germany). To assign all specimens to species groups, two oligonucleotide primers were used for both sequencing and amplification of the COI-5P mitochondrial marker, GWSFn (Le Gall and Saunders 2010) and GWSRx (Saunders and McDevit 2012). A denaturation cycle of $94^{\circ} \mathrm{C}$ for 4 min was followed by $38-42$ cycles of $94^{\circ} \mathrm{C}$ for $1 \mathrm{~min}, 45^{\circ} \mathrm{C}$ for $1 \mathrm{~min}, 72^{\circ} \mathrm{C}$ for $1 \mathrm{~min}$, and a final extension of $72^{\circ} \mathrm{C}$ for $7 \mathrm{~min}$. Specimens were likewise sequenced 
for the plastid-encoded $r b c \mathrm{~L}$ operon. Amplification and/ or sequencing reactions for $r b c \mathrm{~L}$ were conducted using the primers (F43-R753; F615-RrbcS start) and the thermal profile referenced in Wiriyadamrikul et al. (2014). All amplified DNA was treated with the Qiagen (Redwood City, CA, USA) QIAquick PCR Purification Kit following the manufacturer's protocol. The purified PCR product was sequenced at the Rhode Island Genomics and Sequencing Center using the Applied Biosystems Inc. 3130xl Genetic Analyzer (Life Technologies, Grand Island, NY, USA).

COI-5P barcode sequences from representatives in the Galaxauraceae, including some available through GenBank and those newly determined here, were aligned using the MUSCLE (multiple sequence comparison by log-expectation) alignment program in Geneious (v. 6.1.8 available from http://www.geneious.com). To visually characterize genetic variability among specimens, the UPGMA clustering algorithm was applied to the COI-5P alignment (42 specimens, 538 sites) with Tamura-neicorrected distances (default setting). The resulting tree (Figure 1) was used to demarcate species groupings. Based on these genetically related groups (=species), and with comparative data available from GenBank, one specimen from each species and/or geographic location was selected for phylogenetic analysis using $r b c \mathrm{~L}$ sequences (Figure 2). The best models of evolution for the individual gene regions $r b c \mathrm{~L}$ (62 taxa, 1249 sites) were determined in jModelTest 2 (volume 2.1.5; Darriba et al. 2012). The selected phylogenetic model (GTR $+\mathrm{I}+\mathrm{G}$ in both instances) was used to complete both maximum likelihood (ML) and Bayesian analyses for each gene. The ML phylogeny was estimated using the RAxML graphical user interface (Silvestro and

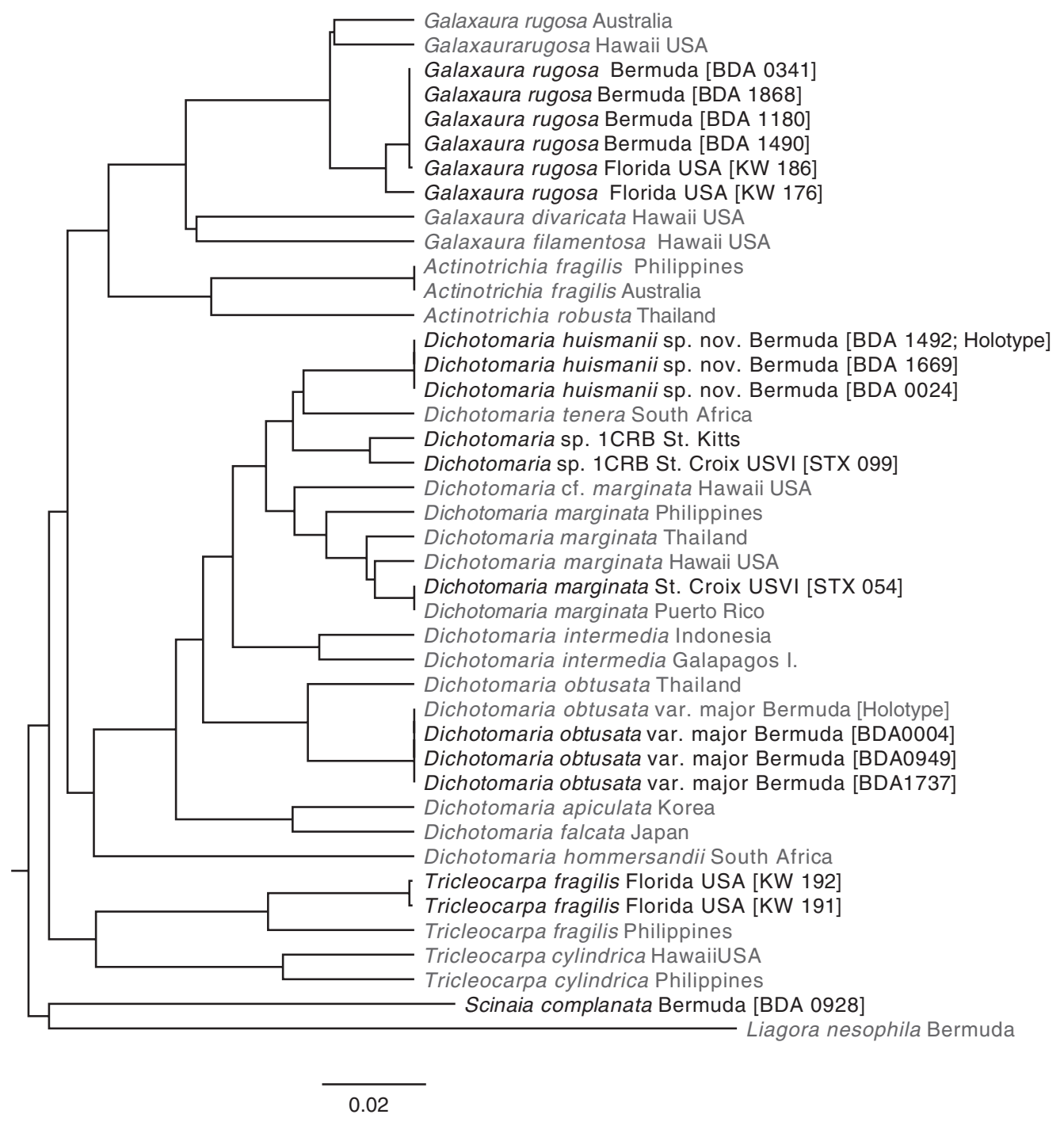

Figure 1: Species groups in the Galaxauraceae determined with UPGMA clustering of the COI-5P genetic barcode, with Scinaia and Liagora as outgroups. Sequences generated for this study are in bold text. 


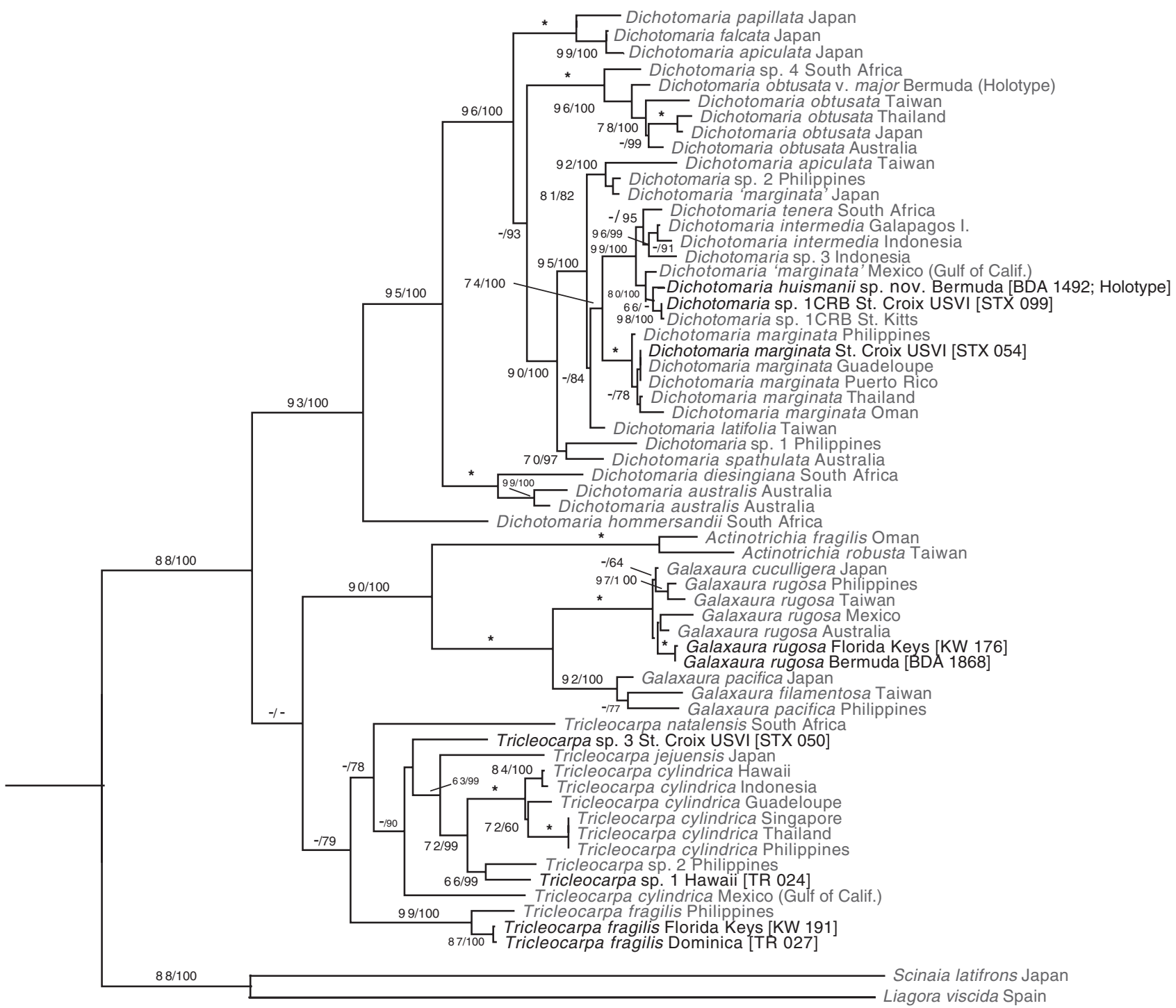

0.08

Figure 2: Phylogeny of the Galaxauraceae based on maximum-likelihood analyses of $r b c L$ sequences. Branch values are bootstrap supports for ML (1000 replicates) followed by Bayesian posterior probabilities expressed as a percentage of support out of 1 . An asterisk (*) indicates $100 \%$ support for both robustness metrics while a dash (-) indicates support values $<60 \%$. Sequences generated for this study are in bold text.

Michalak 2011) with branch support calculated using 1000 bootstrap replicates. Bayesian analysis of $r b c \mathrm{~L}$ was conducted in MrBayes v.3.2.2 (Ronquist and Huelsenbeck 2003) and run with four parallel chains (three heated+one cold) with branch lengths optimized during the run for one million generations. Stationarity was attained after the first 425,000 generations (burnin $=4250$ trees) and posterior probabilities were estimated based on the remaining trees. The $r b c \mathrm{~L}$ phylogenetic tree (Figure 2) includes Liagora and Scinaia as outgroups, and was manipulated for presentation using FigTree software (http://tree.bio. ed.ac.uk/software/figtree/). Specimens used in our molecular analyses are recorded in Table 1.

\section{Results and discussion}

Our $r b c \mathrm{~L}$ results demonstrated that two of our St. Croix isolates (STX032, STX054) were a perfect genetic match with Dichotomaria marginata from Puerto Rico (coll. H. Ruiz, GenBank KC134339) and Guadeloupe (coll. S. Mege, AY680019), but all of the Bermuda sequences and a second species from St. Croix and St. Kitts were genetically distinct (Table 1, Figure 2). For COI-5P, our two identical St. Croix D. marginata specimens (STX032, STX054) were again a perfect match to that from Puerto Rico (Figure 1; this gene was not sequenced for the Guadeloupe isolate). The COI-5P sequence of a second genetic 
species in the D. marginata complex, Dichotomaria sp. 1CRB, was 5.5\% different from D. marginata from St. Croix and Puerto Rico, and only $0.6 \%$ different from specimens under the same name collected in Bermuda. All of the many Bermuda specimens were genetically identical, differing by $4.8 \%$ of their nucleotide base pairs (bp) from D. marginata specimens from Puerto Rico and St. Croix in COI-5P sequences, and 2.4\% from Guadeloupe, Puerto Rico and St. Croix specimens in $r b c \mathrm{~L}$ sequences.

Using D. marginata specimens from St. Croix that genetically matched those from Guadeloupe and Puerto Rico, we completed a morphological assessment of characteristics and found them to conform to descriptive accounts of this species from the geographic area including the type locality. The protologue and other early accounts offered little in the way of specifics other than overall morphology, Ellis and Solander (1786, p. 115) fully describing it as a "Dichotomous coralline with flat smooth branches, scarcely jointed, and a raised border". In fact, this would describe any of the flattened Dichotomaria specimens we have located in the western Atlantic, and is thus of little use in distinguishing similar species with flattened axes in the Caribbean and surrounding areas. It would seem obvious, then, that 20th century and later accounts of $D$. marginata in the western Atlantic (e.g. Kjellman 1900, Børgesen 1916, Taylor 1928, 1960, Littler and Littler 2000, Dawes and Mathieson 2008) could have included observations and measurements from more than a single species with flattened axes.

Therefore, our St. Croix D. marginata specimens that genetically match $r b c \mathrm{~L}$ sequences from Guadeloupe and Puerto Rico, the latter being a genetic standard for D. marginata set by Huisman et al. (2004), can be used to provide a set of morphological characteristics to distinguish our other genetic species from Bermuda and the Caribbean. The report of $D$. marginata by Collins and Hervey (1917) was made using widely distributed Bermuda specimens (P.B.-A. no. 1930) and therefore represents the segregate species we describe and differentiate in the $D$. marginata complex below.

\section{Dichotomaria marginata (J. Ellis et Solander) Lamarck 1816, p. 146 (Figures 3-6)}

\section{Basionym}

Corallina marginata J. Ellis et Solander 1786, p. 115, pl. 22 figure 6 (Figure 3).

\section{Description}

Rosy-brown plants to $10 \mathrm{~cm}$ tall and $13 \mathrm{~cm}$ across, composed of dichotomously branched flattened axes with thickened margins, these showing faint annulations; axes mottled in appearance when dried; internodes $4.7-13.7 \mathrm{~mm}$ long and 1.6-2.6 mm wide; axes branching dichotomously at angles of $72-89^{\circ}$; cortex of sporophytes composed of two layers of cells, outer cortical assimilatory cells subspherical to ovoid, 20-40 $\mu \mathrm{m}$ long and (21-) 33-49 $\mu \mathrm{m}$ diameter, and an inner layer of flared stalk cells each bearing 1-2 assimilatory cells, $15-36 \mu \mathrm{m}$ long and 5-10 $\mu \mathrm{m}$ diameter (at narrowest point); stalk cells borne typically in pairs though occasionally singly on the outer surface of the inner cortex; stalk cells most commonly unicellular, rarely two-celled; inner cortex consisting of typically one, occasionally two, layers of transversely ovoid to rectangular cells, 50-115 $\mu \mathrm{m}$ diameter and 25-68 $\mu \mathrm{m}$ high; subcortical cells subspherical at margins; medullary filaments extending from subcortical cells, 7-13 $\mu \mathrm{m}$ diameter; gametangia and tetrasporangia not seen in our sequenced specimens.

\section{Type locality}

"... on the shore of one of the Bahama islands", West Indies, western Atlantic Ocean (Ellis and Solander 1786).

\section{Distribution}

Formerly reported as pantropical, genetically verified specimens are known from Guadeloupe, Puerto Rico and St. Croix, USVI (West Indies).

\section{Selected collections}

St. Croix, Virgin Is. - T.R. Popolizio (TRP)/C.E. Lane (CEL)/ E.D. Salomaki (EDS) 13-24-1 [STX032] (Figure 4), TRP/CEL/ EDS 13-25-9 [STX054] (see Table 1 for collection details).

\section{Remarks}

As discussed above, two St. Croix collections genetically matched other sequenced specimens from Guadeloupe and Puerto Rico, as well as the description of Dichotomaria marginata provided by Papenfuss et al. (1982). This has allowed us to identify STX032 and STX054 (Figures 1 and 2) as true representatives of $D$. marginata in the West 


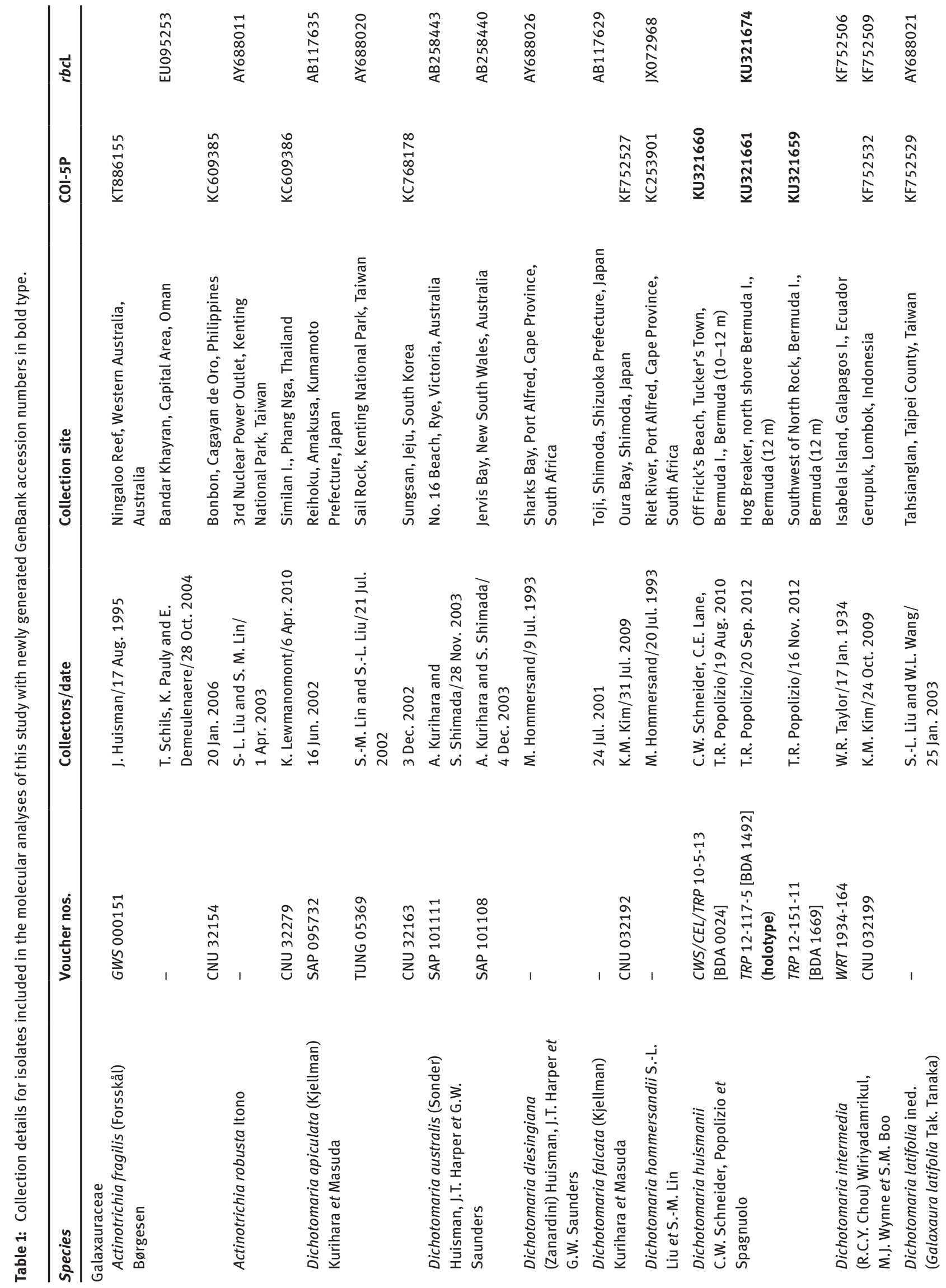




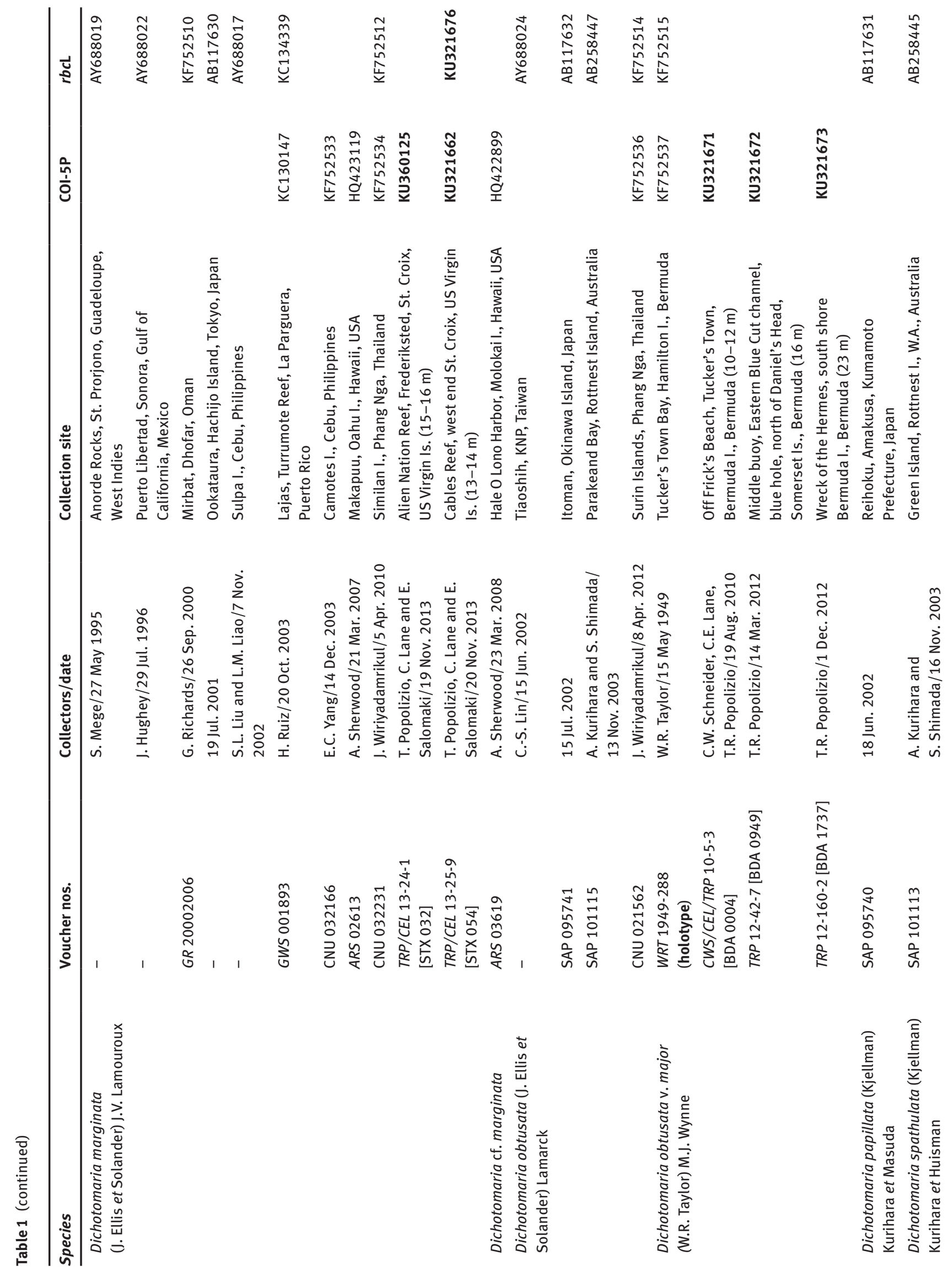




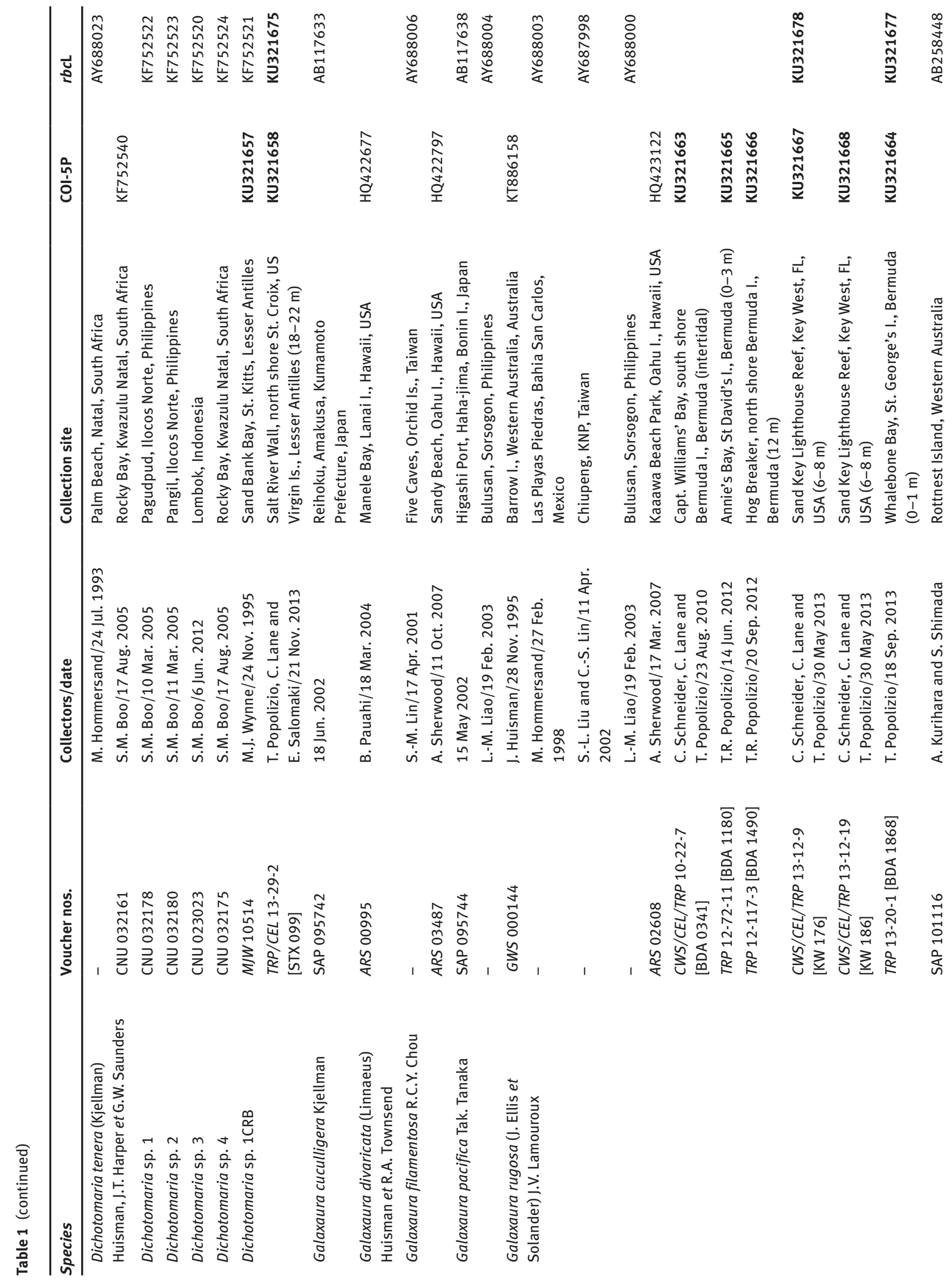




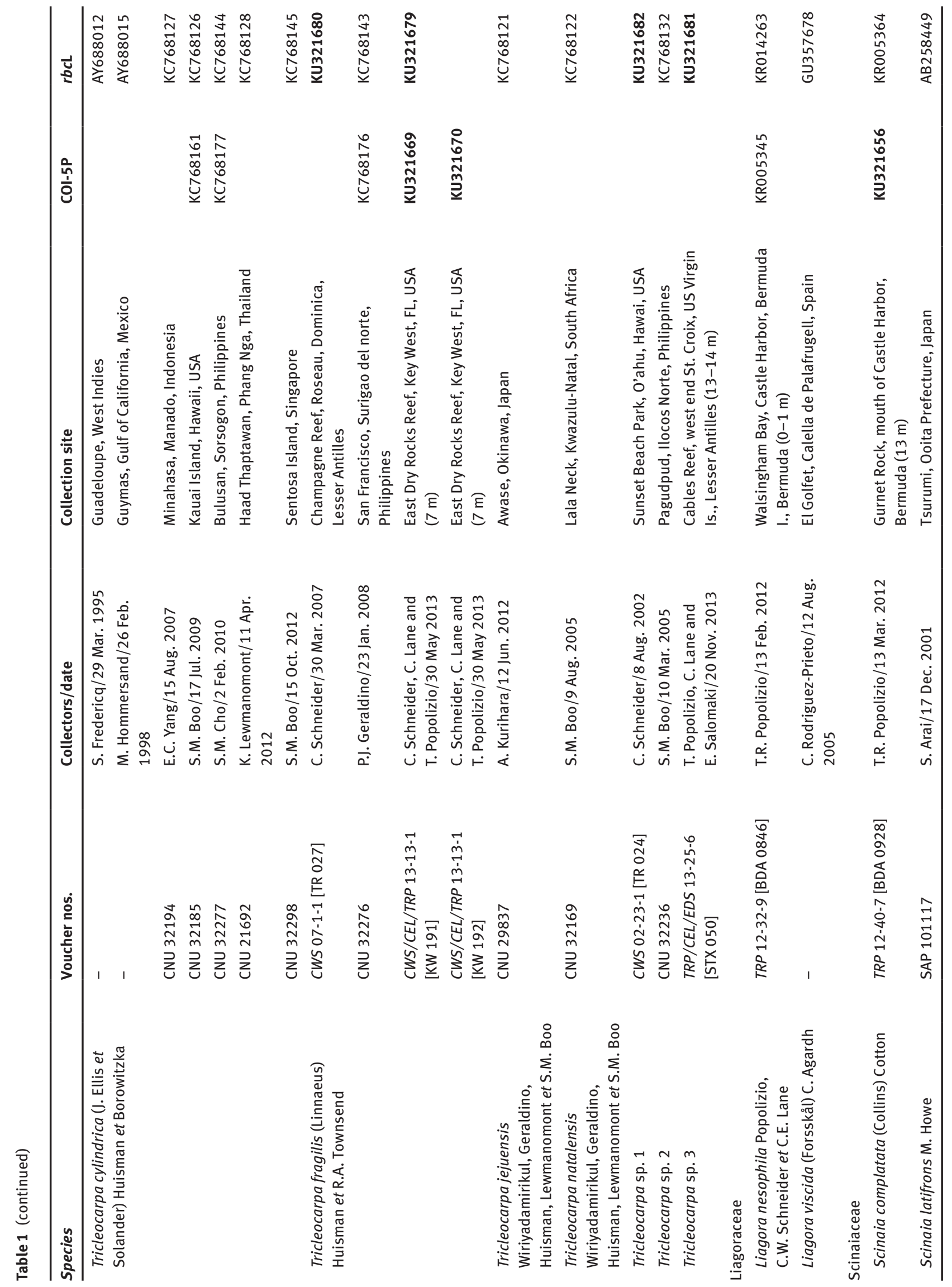




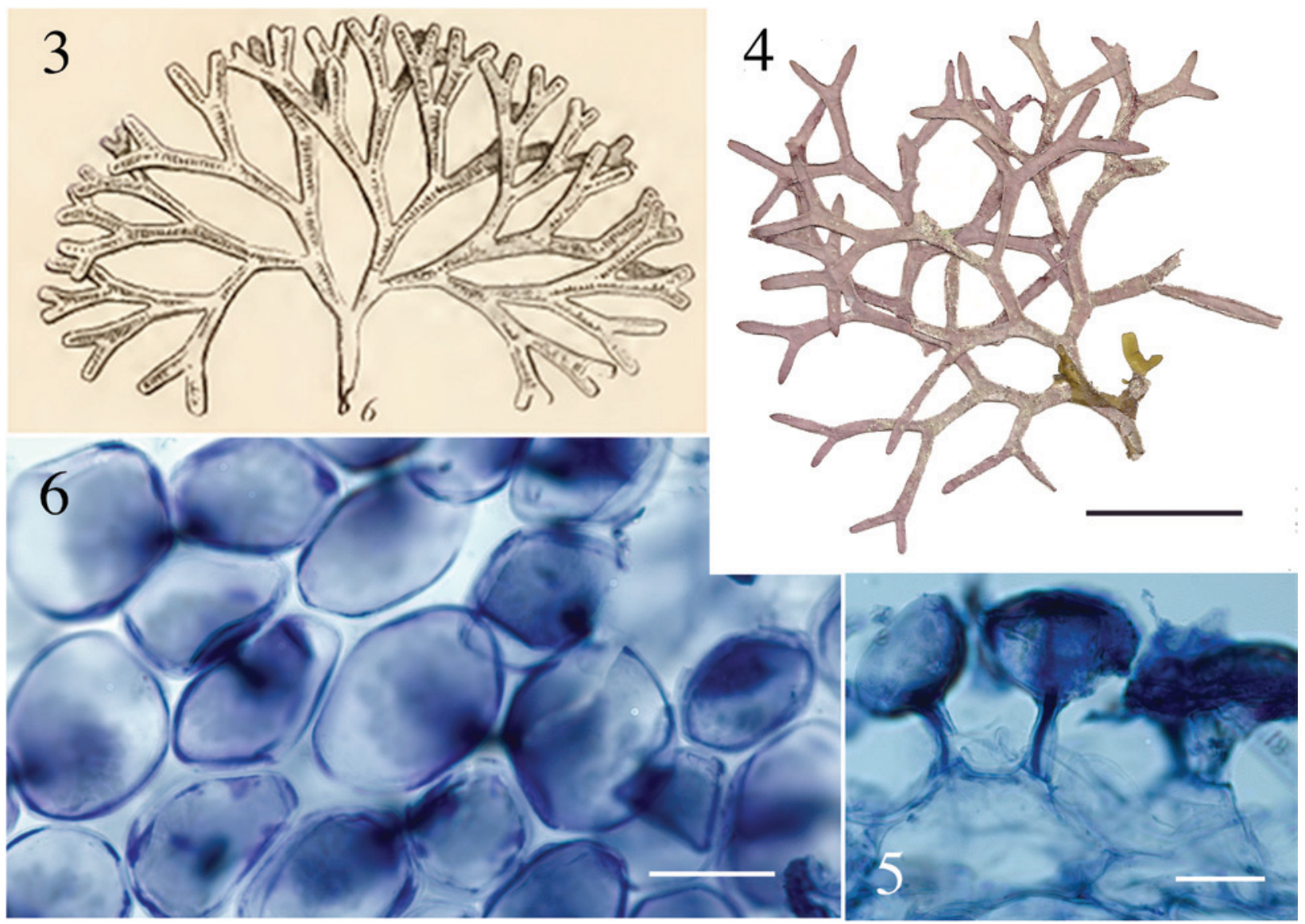

Figures 3-6: Dichotomaria marginata.

(3) Lectotype of Corallina marginata (=Dichotomaria marginata): Ellis and Solander illustration (1786, pl. 22 figure 6). (4) Sample from St. Croix (STX032), scale bar $=2 \mathrm{~cm}$. (5) Section through outer cortex showing subcortical cell bearing a pair of assimilatory outer cortical cells, scale bar $=25 \mu \mathrm{m}$. (6) Surface view of outer cortical assimilatory cells (STX054), scale bar $=25 \mu \mathrm{m}$.

Indies, a species with a type locality in the Bahamas (Silva et al. 1996). All of the genetic collections made in St. Croix identified as D. marginata have the anatomy of sporophytes defined for the species, unfortunately none bearing tetrasporangia. Thus, we cannot provide tetrasporangial size and shape nor the anatomy or reproduction in gametophytes of these genetically significant $D$. marginata vouchers. Although there are reports about these features in earlier literature (e.g. Børgesen 1916, Howe 1918b, Taylor 1960, Papenfuss et al. 1982), without a molecular tie to this species where crypsis is now reported, we are hesitant to link that information here.

Similar to what Huisman et al. (2004) found for the species, tetrasporic St. Croix representatives of D. marginata have "the presence of a distinctly thickened margin (particularly noticeable when dried)" and a "cortex of the tetrasporophyte bearing paired subspherical cells (at least some with a small terminal spine)" (Figure 5). As was pointed out in the Ellis and Solander (1786) protologue, the flattened axes of $D$. marginata are more pronounced when removed from the water, the first collections being washed up and dried on a Bahamian beach. Our specimens have three, or occasionally four, layers of cells including stalk and outer assimilatory cells. The assimilatory cells of St. Croix D. marginata are subspherical to ovoid in cross-section (Figure 5), and appear circular to ellipsoidal in surface view (Figure 6). Some, but not a majority, of the assimilatory cells are apiculate, these cells usually paired on stalk cells that are mostly paired on outer subcortical cells (Figure 5). The subcortical cells are transversely ovoid to rectangular, and occasionally subspherical at the margins (Figure 5).

Howe (1918b) was the first to consider Galaxaura occidentalis Børgesen (type locality=Virgin Islands) as the gametophyte generation of $G$. marginata, and Børgesen (1920) and subsequent workers (Taylor 1960, Papenfuss et al. 1982) followed his supposition. Howe (1918a) mentioned gametophytic specimens in his account of G. marginata in the Bermuda flora, but it remains unclear whether he was referring to actual Bermuda gametophytes or 
rather to the gametophytes he was working on at the same time from the West Indies (Howe 1918b). We have been able to observe the gametophytic holotype of $\mathrm{G}$. occidentalis [in $\mathrm{C}$ ], most reasonably the alternate generation of the sporangial $D$. marginata, but this requires genetic confirmation. It would be helpful to find sporophytes and gametophytes of $D$. marginata in a single Bahamian or West Indian population to confirm this supposition, both generations matching genetic sequences already linked to this species from the West Indies.

A second genetic species, Dichotomaria sp. 1CRB, was collected in St. Croix and St. Kitts (Figures 1 and 2, Tables 1 and 2), and the St. Croix isolate represents the gametophytic stage of an undescribed species in the D. marginata complex. The St. Croix specimen has anatomical similarities with the type of $G$. occidentalis; unfortunately, it is genetically distinct from local and regional $D$. marginata. We only have two representatives of this species from the West Indies, thus until additional specimens are obtained and sequenced, Dichotomaria sp. 1CRB will remain undescribed. Whether its gametophytic stage represents what was described as G. occidentalis requires further investigation. Nevertheless, its sequence demonstrates that there are at least two species in the $D$. marginata complex in the West Indies.

\section{Dichotomaria huismanii C.W. Schneid., Popolizio et Spagnuolo sp. nov. (Figures 7-13)}

\section{Description}

Rosy-brown plants to $8 \mathrm{~cm}$ tall and $12 \mathrm{~cm}$ across, composed of dichotomously branched, flattened axes with thickened margins above, the axes subterete below; axes mottled in appearance when dried, annulations, when present, faint; internodes 3-9 $\mathrm{mm}$ long and 1.2-2.0 mm wide; axes branching dichotomously at angles of (32-) 41-54 $\left(-68^{\circ}\right)$; cortex of sporophytes composed of two layers of cells, outer cortical assimilatory cells subspherical to ovoid, 28-50 $\mu \mathrm{m}$ length and 22-48 $\mu \mathrm{m}$ diameter, and an inner layer of flared stalk cells, each bearing one or two assimilatory cells, $23-45 \mu \mathrm{m}$ length and 5-13 $\mu \mathrm{m}$ diameter at narrowest point; stalk cells borne typically in pairs though occasionally alone on the outer layer of the inner cortex; stalk cells unicellular; inner cortex consisting of two layers of transversely ovoid to rectangular cells, 24-44 (-70) $\mu \mathrm{m}$ long and (38-) 58-89 $\mu \mathrm{m}$ diameter; subcortical cells subspherical at margins; medullary filaments extending from subcortical cells, closely adherent and parallel, running longitudinally the length of the axis, 13-20 $\mu \mathrm{m}$ diameter; tetrasporangia and gametophytes unknown.

\section{Etymology}

The epithet "huismanii" honors Dr. John M. Huisman, the foremost expert on the Nemaliales today, for, among other things, his prolific systematic work on the order over the past three decades, culminating in his recognition of the D. marginata complex using genetic techniques (Huisman et al. 2004, Kurihara and Huisman 2006).

\section{Holotype}

T.R.Popolizio 12-117-5 [BDA1492], 20 Sept.2012, Hog Breaker, north shore Bermuda I., 32 $27^{\prime} 47.7^{\prime \prime} \mathrm{N}, \quad 64^{\circ} 49^{\prime} 48.9^{\prime \prime} \mathrm{W}$, Bermuda, western Atlantic Ocean, depth $12 \mathrm{~m}$ [MICH] (Figure 8); isotype Herb. CWS.

\section{Paratypes}

Bermuda - A.B. Hervey, P.B.-A. no. 1930 [Collins et al. 1913, as Brachycladia marginata], 22 Jan. 1913, near low water mark south shore, Bermuda I. [Herb. CWS] (Figure 7); CWS/CEL 10-5-13 [BDA0024], 19 August 2010, reef off Frick's Beach, $32^{\circ} 19^{\prime} 56.0^{\prime \prime} \mathrm{N}, 64^{\circ} 40^{\prime} 20.7^{\prime \prime} \mathrm{W}$, Tucker's Town, Bermuda I., depth 10-12 m (Figure 9); TRP/CWS 12-151-11 [BDA1669], TRP/CWS 12-158-3 [BDA1709], TRP/CWS 12-170-9 [BDA1805] (see Table 1 for collection details).

\section{Distribution}

Endemic to Bermuda as presently known.

\section{Remarks}

The new species is presently very rare in Bermuda and, when found, there are few individuals in the population. When Collins and Hervey (1917) first reported Galaxaura marginata from Bermuda, they cited only their shallow water collection from Gravelly Bay (P.B.-A. no. 1930; Figure 7), but clearly there were enough specimens available at the time to make herbarium specimens for 
Table 2: Morphological characters of sequenced isolates used for genetic comparison of western Atlantic species in the Dichotomaria marginata complex.

\begin{tabular}{|c|c|c|c|}
\hline Species & Dichotomaria marginata & Dichotomaria huismanii sp. nov. & Dichotomaria sp. 1CRB \\
\hline Plant height (cm) & To 10 & To 8 & To 11 \\
\hline Plant width $(\mathrm{cm})$ & To 13 & To 12 & To 14 \\
\hline Axis in transverse section & Flattened throughout & Subterete below, flattened above & Flattened throughout \\
\hline Branch angles & $72-89^{\circ}$ & $(32-) 41-54(-68)^{\circ}$ & $41-89^{\circ}$ \\
\hline Internode length (mm) & $4.7-13.7$ & $3-9$ & $4.8-13.3$ \\
\hline Internode width (mm) & $1.6-2.6$ & $1.2-2.2$ & $1.0-2.1$ \\
\hline Annulations & Faint & Faint when present & Faint to strong \\
\hline \multicolumn{4}{|l|}{ Sporophyte } \\
\hline Cortical cell layers & $\begin{array}{l}3 \text {, rarely } 4 \text {, including stalk } \\
\text { cells }\end{array}$ & 4 including stalk cells & 4 including stalk cells \\
\hline Outer cortical cells & $\begin{array}{l}\text { Ovoid to subspherical } \\
\text { in section, circular to } \\
\text { ellipsoidal in surface view }\end{array}$ & $\begin{array}{l}\text { Ovoid to subspherical in section, } \\
\text { irregularly polygonal in surface } \\
\text { view }\end{array}$ & $\begin{array}{l}\text { Ovoid to lanceolate in } \\
\text { section, polygonal in surface } \\
\text { view }\end{array}$ \\
\hline Outer cortical cell height $(\mu \mathrm{m})$ & $20-40$ & $28-50$ & $34-50$ \\
\hline Outer cortical cell diameter $(\mu \mathrm{m})$ & $(21-) 33-49$ & $22-48$ & $17-34$ \\
\hline Apiculae on outer cortical cells & Rare & Absent & Numerous \\
\hline Stalk cell length $(\mu \mathrm{m})$ & $15-36$ & $23-45$ & $25-41$ \\
\hline Stalk cell, center diameter $(\mu \mathrm{m})$ & $5-10$ & $5-14$ & $7-15$ \\
\hline Subcortical cell length $(\mu \mathrm{m})$ & $25-68$ & $21-48(-70)$ & $27-43$ \\
\hline Subcortical cell diameter $(\mu \mathrm{m})$ & $50-115$ & $(32-) 60-93$ & $21-30$ \\
\hline Medullary filament diameter $(\mu \mathrm{m})$ & $7-13$ & $13-26$ & $6-15$ \\
\hline Type locality & Bahamas Is., West Indies & Bermuda & - \\
\hline Collection region of specimens & St. Croix, USVI, West Indies & Bermuda & St. Kitts, St. Croix \\
\hline
\end{tabular}

each of the 80 distributed sets of the exsiccata they were ultimately placed in (Fahey and Doty 1955). Collins and Hervey (1917) did not distinguish their collections in any feature from the standard characteristics of $G$. marginata taken from earlier sources available to them at the time. Interestingly, all of the Dichotomaria huismanii specimens we have collected show many truncated branch tips that have been grazed by herbivores (Figures 8 and 9). Often on these plants, closely adherent medullary filaments that run longitudinally through the axes emerge from the truncated tips, and occasionally from branch nodes, as caespitose tufts of loose, uniseriate filaments, appearing much like a dense epiphytic growth of an acrochaetioid alga (Figures 8 and 9; we sequenced these tufts and they were a $100 \%$ match to the macroscopic plant on which they form). Taylor (1960) may have observed the same for D. marginata when he mentioned "branches occasionally tipped with a brush of deciduous hairs", but he made no mention of herbivory. It is worth noting that all of our recent collections from Bermuda are much smaller (to $4 \mathrm{~cm}$ tall, $7 \mathrm{~cm}$ across) and less robust than those distributed in 1913 fascicles of P.B.-A (8 cm tall, $12 \mathrm{~cm}$ across; Figure 7$)$. The reduced habit appears to be a trend seen in many seaweeds collected in Bermuda during the latter part of the 20th and first part of the 21st centuries, these being smaller than herbarium collections made in the early years of the 20th century. We believe increased fish herbivory in Bermuda may be responsible for the more diminutive plants of today, as was shown for two small Botryocladia spp. growing on the reefs compared to large, fully formed, non-grazed plants in display tanks of the Bermuda Aquarium (Schneider and Lane 2008). Increased herbivory could also account for the fewer individuals found today in Bermuda populations as compared with the distant past, as well as a lack of specimens from shallow waters, the only habitat reported for this species by Collins and Hervey (1917).

Thus far, the new species is known only from Bermuda and represents the only flattened member of the genus in the local flora. Dichotomaria huismanii is genetically distinct from $D$. marginata in the West Indies $(4.8 \% \mathrm{bp}$ differences in COI-5P sequences, $2.4 \%$ in $r b c \mathrm{~L}$ ), the islands of Bermuda being isolated from the closest populations of the generitype by a distance $>1350 \mathrm{~km}$ to the northeast of the Bahamas. St. Kitts/St. Croix isolates (Dichotomaria sp. 1CRB, Table 1) are sister to the new species in the COI-5P tree (Figure 1), but show $4.1 \%$ bp differences with it (22 nucleotide differences out of 538). The $r b c L$ clade where $D$. huismanii is resolved (Figure 2) also includes a specimen identified as " $D$. marginata" from the Gulf of California (GenBank AY688022). The $r b c \mathrm{~L}$ sequences from Bermuda and Mexico are 0.6\% different from each other (there is no COI-5P data for the Mexican 

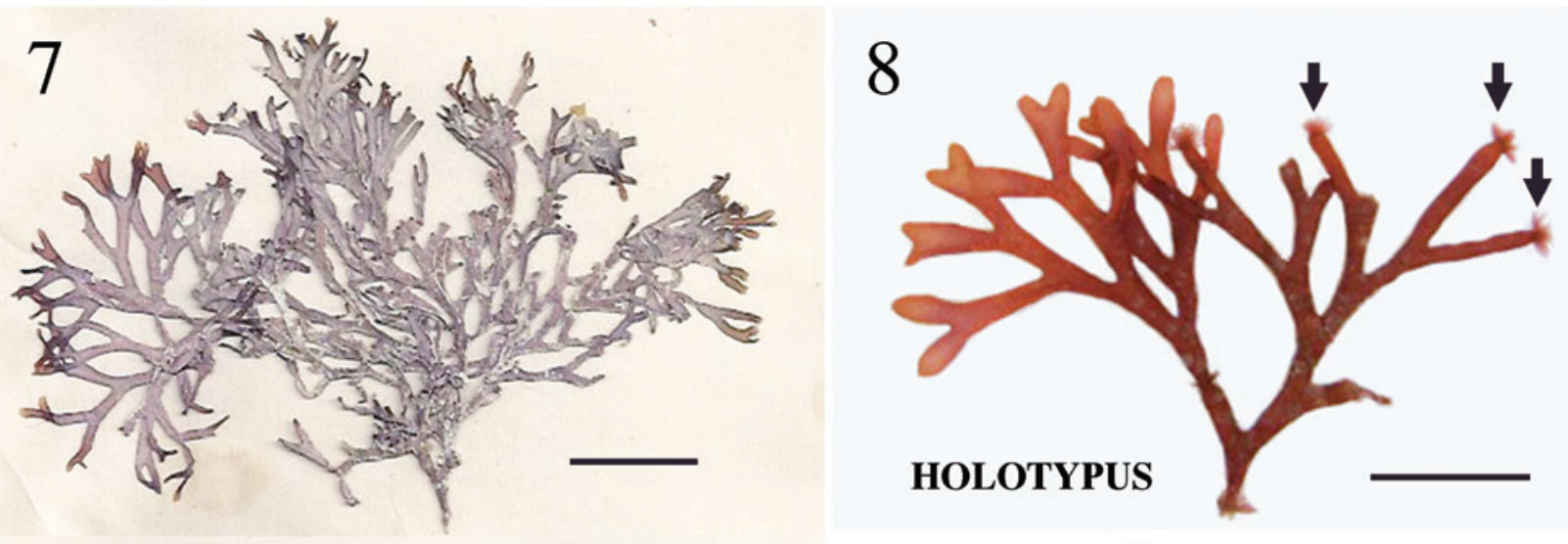

Phycotheca Boreali-Americana,

Collins, Holden and Setcheil. Algae of Bermuda.

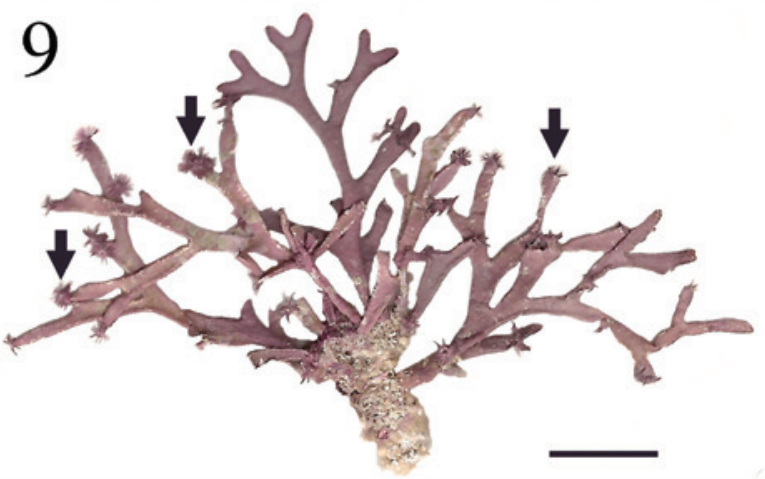

1930. Brachyeladia marginata (Ell. \& Sol.) Schmitz.

Schmitz, Syst. Uebersicht Florid., p. 4, 1859 De Toni, Syll. Alg., Vol. IV, p. 109, 1897. Corallina marginata Ellis \& Solander, Nat. Hist. Zoophytes, p. 115 , Pl. XX, fig. 6,1786 .

Galaxaura marginata Lamouroux, Hist. Pol. Flex., p. 264, 1816.

Collins, Proc. Amer. Acad., Vol. XXXVII, p. 252, 1901. Zanardinia marginata J. G. Agardh, Sp. Alg., Vol. III, p. $534,1876$.

Near low water mark, south shore, Jan. 22, 1913. A. B. HERVEY.
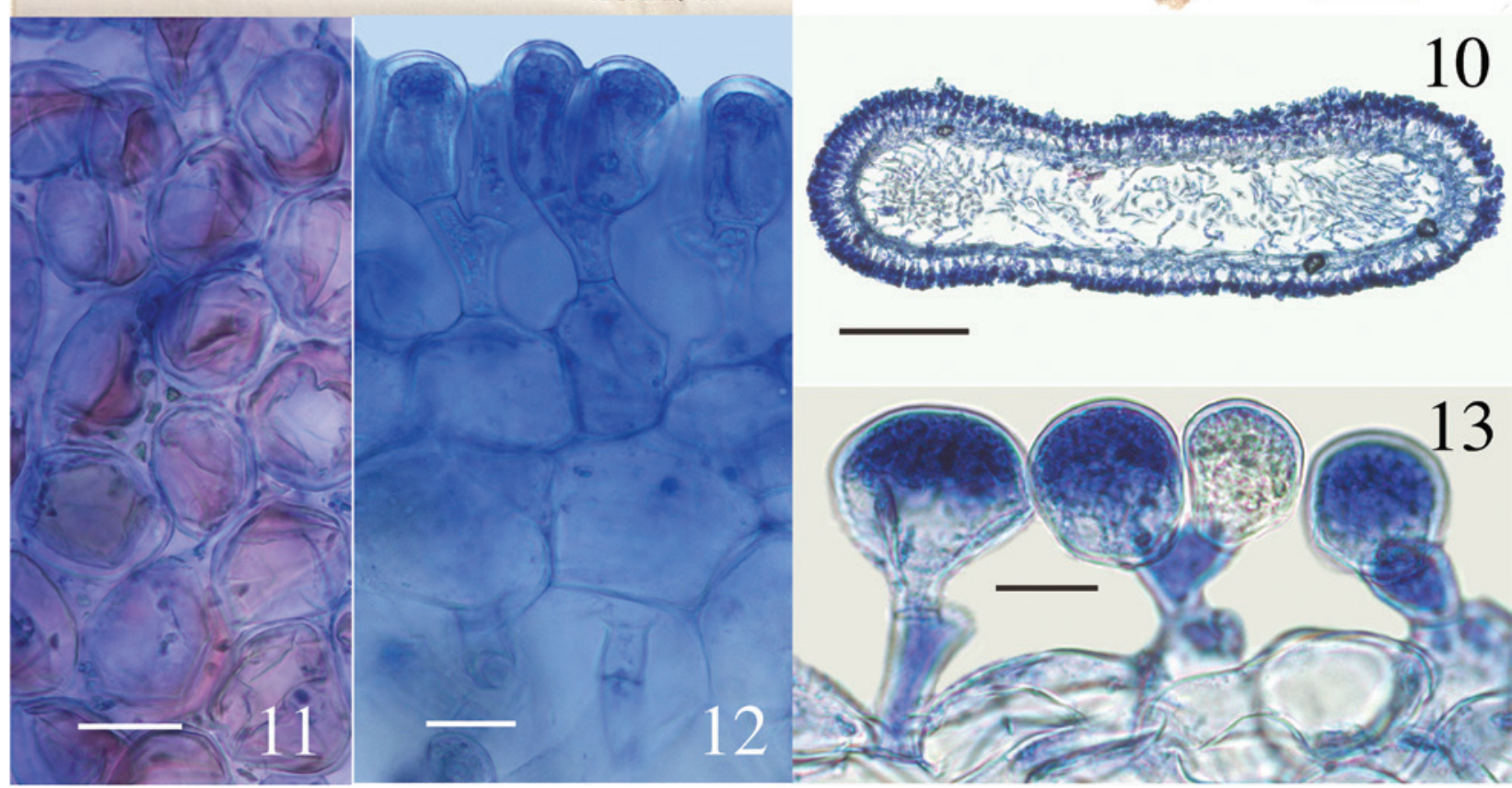

Figures 7-13: Dichotomaria huismanii sp. nov.

(7) Bermuda P.B.-A. no, 1930, as Brachycladia marginata, scale bar $=2 \mathrm{~cm}$. (8) Holotype specimen [BDA1492]; truncated axes with emergent medullary filaments (arrows), scale bar $=1 \mathrm{~cm}$. (9) Paratype specimen [BDA0024]; truncated axes with emergent medullary filaments (arrows), scale bar $=1 \mathrm{~cm}$. (10) Transverse section of axis [BDA1709], scale bar $=200 \mu \mathrm{m}$. (11) Surface view of outer cortical assimilatory cells [BDA0025], scale bar $=25 \mu \mathrm{m}$. (12) Section through axis showing two subcortical cell layers bearing pairs of ovoid outer cortical assimilatory cells and medullary connections [BDA0025], scale bar $=20 \mu \mathrm{m}$. (13) Section through cortex showing subcortical cells bearing pairs of subspherical outer cortical assimilatory cells [BDA1492], scale bar $=20 \mu \mathrm{m}$. 
isolate). The Bermuda and Mexico species are each 0.6\% different in $r b c L$ bp from the two Caribbean sequences of Dichotomaria sp. 1CRB (Table 1).

Aside from the geographic separation and genetic difference, a few morphological characteristics present themselves as means for differentiating $D$. huismanii from its cryptic counterpart in the western Atlantic, $D$. marginata. In gross morphology, $D$. huismanii is difficult to distinguish from $D$. marginata, but subtle differences can be found anatomically. The dimensions of cortical cells, thallus height and width, and the length and width of internodes all demonstrate a great amount of overlap between the two species (Table 2). But unlike D. marginata, none of the assimilatory cells on $D$. huismanii are apiculate (Figures 11-13), a character that may be of use in western Atlantic populations of Dichotomaria after a more thorough examination of isolates is made from the region of the Bahamas, throughout the Caribbean and south to Brazil. The new species has four cortical cell layers including stalk and outer assimilatory cells (Figure 12) and in general has greater diameter medullary filaments (13-20 $\mu \mathrm{m})$ than the generitype $D$. marginata $(7-13 \mu \mathrm{m})$, which mostly shows three cortical cell layers (Figure 5). The dichotomous axes of $D$. huismanii branch at markedly narrower angles than St. Croix specimens of $D$. marginata, $32-68^{\circ}$ vs. $72-89^{\circ}$. Whether any of these anatomical character differences will hold up as more isolates from the Caribbean are sequenced remains to be seen.

Using the chloroplast $r b c \mathrm{~L}$ gene, along with the western Atlantic species mentioned above, D. huismanii clusters with two Indo-Pacific species, $D$. tenera and $D$. intermedia (Figure 2). The only detailed description of $D$. tenera since its genetic analysis and resurrection by Huisman et al. (2004) is found in De Clerck et al. (2005) based on specimens from Kwazulu-Natal, South Africa, the geographic area from which Huisman et al. (2004) used isolate sequences to segregate it from Caribbean $D$. marginata. These Indian Ocean specimens have somewhat broader flattened branches (1.5$3.0 \mathrm{~mm}$ ) than $D$. huismanii (1.2-2.2 $\mathrm{mm}$ ), and unlike the new species have axes that are hirsute above the holdfasts and produce outer cortical cells that are apiculate at the margins (De Clerck et al. 2005). Specimens of D. tenera from Mauritius are reported to have outer cortical cells that are 38-42 $\mu \mathrm{m}$ tall and 27-30 $\mu \mathrm{m}$ diameter (Børgesen 1942, as Galaxaura tenera Kjellman), well within the range of these cell sizes in D. huismanii. Their branch angles (measured from Børgesen 1942, figure 24) are from $50-75^{\circ}$, a slightly wider angle range than that of the new species reported here (Table 2). A specimen attributed to $D$. tenera from South Africa and pictured by Kylin (1938), as G. tenera), has much narrower branch angles, 40-55 , than the Mauritian sample.
The second species that genetically clusters with Dichotomaria huismanii (Figure 2), D. intermedia (R.C.Y. Chou) Wiriyadamrikul, M.J. Wynne et S.M. Boo (type locality=Galapagos Is.), is considerably larger (to $23 \mathrm{~cm}$ ) than the new species (to $8 \mathrm{~cm}$ ). Despite its overall large size, D. intermedia has similar cell dimensions for outer cortical cells on tetrasporophytes, 30-50 $\mu \mathrm{m}$ tall and 25-35 $\mu \mathrm{m}$ diameter (Wiriyadamrikul et al. 2014), as compared to those for $D$. huismanii, 28-50 $\mu \mathrm{m}$ tall and 22-48 $\mu \mathrm{m}$ diameter (Table 2), but unlike the new species, these cells are apiculate.

Morphological comparisons of Galaxaura and Dichotomaria species from locations other than their type localities with species from different parts of the world create similar problems to those we have already alluded to for genetic data from distant locations. For example, prior to the availability of molecular sequencing and comparison of species, Chou (1945) used Pacific Costa Rican samples of G. stupocaulon Kjellman (type locality=Brazil) to characterize this species, and make comparisons with other members that would be included in the $D$. marginata complex today (Huisman et al. 2004, Wang et al. 2005, Kurihara and Huisman 2006, Wiriyadamrikul et al. 2014). Oliveira (1977) noted the "great similarity" of Galaxaura angustifrons Kjellman (type locality=Brazil) from Brazil to $G$. veprecula Kjellman (type locality=Madagascar) from the Philippines and Ecuador based on Chou's (1947) observations and measurements. G. veprecula was subsequently placed in synonymy with G. tenera by Papenfuss and Chiang (1969), species later subsumed in G. marginata (Papenfuss et al. 1982). Finally, G. tenera was resurrected as Dichotomaria tenera by Huisman et al. (2004) based on LSU sequence data (and the morphology of terminal cortical cells) of specimens from South Africa. It seems obvious from these convoluted pathways that historical taxonomic decisions involving Galaxaura and Dichotomaria species need to be reassessed from the fresh perspective of DNA sequencing, as has been done in selected recent studies (Huisman et al. 2004, Wang et al. 2005, Kurihara and Huisman 2006, Wiriyadamrikul et al. 2014). Accordingly, what has been combined in the past under $D$. marginata, has already begun fragmenting back to a greater number of species.

For their Indian Ocean and Australian specimens of Dichotomaria "marginata", Huisman et al. (2004) were able to resurrect species names for flattened taxa from those areas with specimens that did not genetically match the sequence of true $D$. marginata from Puerto Rico. The resurrected $D$. australis and $D$. tenera had been among a large number of species that, over the years and culminating with the Papenfuss et al. (1982) circumscription, were placed in synonymy with $D$. marginata. In the western Atlantic, there are early names presently considered junior 
synonyms of D. marginata: G. angustifrons, G. frutescens Kjellman (type locality=Brazil), G. occidentalis and $G$. stupocaulon. None of these taxa were ever reported from Bermuda (Taylor 1960). The above three species presently in the D. marginata complex with type localities in Brazil do share some resemblance to both $D$. marginata and $D$. huismanii, and are presently considered synonyms of the former. Observations for these species on type specimens is critical to linking anatomical measurements/characteristics to recently collected genetic species from near their type localities in this highly cryptic complex of species. As none of the historical species were described locally, we choose to describe our Bermuda specimens as a new species from the northern limit of distribution of the genus in the western Atlantic. Genetic information from other areas to the south may prove this species to have a more widespread distribution than presently delimited.

The separation and description of a new cryptic species from Bermuda for records that in the past were considered a part of a pantropical species' range with a western Atlantic type is similar to other nemalialean examples already genetically distinguished in the islands. What was identified in Bermuda as Helminthocladia calvadosii (J.V. Lamouroux ex Duby) Setchell for over a century was shown to be H. kempii Popolizio, Chengsupanimit et C.W. Schneider (Popolizio et al. 2013), and what was known as Liagora ceranoides J.V. Lamouroux since the early 1900s in the islands was recently described as L. nesophila Popolizio, C.W. Schneider et C.E. Lane (Popolizio et al. 2015).

Acknowledgments: We thank Dr. Nina Lundholm and the Natural History Museum of Denmark [C] for a loan of the holotype of Galaxaura occidentalis, Dr. Michael Wynne [MICH] for a loan of Caribbean specimens, and Eric Salomaki for helping collect in St. Croix and sequencing the holotype of the new species. Dr. Struan Smith of the Bermuda Natural History Museum and Chris Flook of St. David's, Bermuda, kindly provided logistical support for several collecting trips in Bermuda. CWS and CEL were funded by NSF DEB grants 1120688 and 1120652 as well as the Charles A. Dana Foundation. This is Contribution no. 230 to the Bermuda Biodiversity Project (BBP) of the Bermuda Aquarium, Natural History Museum and Zoo (BAMZ), Department of Conservation Services.

\section{References}

Børgesen, F. 1916. The marine algae of the Danish West Indies, Part 3: Rhodophyceae (2). Dansk Bot. Arkiv 3: 81-144.
Børgesen, F. 1920. The marine algae of the Danish West Indies, Part 3: Rhodophyceae (6), with addenda to the Chlorophyceae, Phaeophyceae, and Rhodophyceae. Dansk Bot. Arkiv 3: 369-498.

Børgesen, F. 1942. Some marine algae from Mauritius, III: Rhodophyceae, Part I: Porphyridiales, Bangiales, Nemalionales. $\mathrm{Kgl}$. Danske Vidensk. Selsk., Biol. Medd. 17: 1-85, 1 pl.

Brummitt, R.K. and C.E. Powell. 1992. Authors of plant names. Royal Botanic Gardens, Kew. pp. 732.

Chou, R.C.-Y. 1945 [1944]. Pacific species of Galaxaura. I. Asexual types. Pap. Mich. Acad. Sci., Arts and Lett. 30: 35-56, 2 figs, pls 1-11.

Chou, R.C.-Y. 1947 [1945]. Pacific species of Galaxaura. II. Sexual types. Pap. Mich. Acad. Sci., Arts and Lett. 31: 3-24, 3 figs, pls $1-8$.

Collins, F.S. and A.B. Hervey. 1917. The algae of Bermuda. Proc. Am. Acad. Arts and Sci. 53: 1-195.

Collins, F.S., I. Holden and W.A. Setchell. 1913. Phycotheca BorealiAmericana (Exsiccata), Algae of North America. Fascicle XXXIX. Algae of Bermuda. Nos. 1901-1950. Malden, MA.

Darriba, D., G.L. Taboada, R. Doallo and D. Posada. 2012. jModelTest 2: more models, new heuristics and parallel computing. Nat. Meth. 9: 772.

Dawes, C.J. and A.C. Mathieson. 2008. The seaweeds of Florida. University Press of Florida, Gainesville. pp. 592.

De Clerck, O., J.J. Bolton, R.J. Anderson and E. Coppejans. 2005. Guide to the seaweeds of Kwazulu-Natal. Scripta Botanica Belgica 33: 1-294.

Ellis, J. and D. Solander. 1786. The natural history of many curious and uncommon zoophytes, collected from various parts of the globe by the late John Ellis... Systematically arranged and described by the late Daniel Solander. B. White \& Son, London. pp. $x i i+208,63$ pls.

Fahey, E.M. and M.S. Doty. 1955. An alphabetical index to the Phycotheca Boreali-Americana, prepared from the card index at the Marine Biological Laboratory, Woods Hole, MA. Mimeographed. pp. 37.

Guiry, M.D. and G.M. Guiry. 2015. AlgaeBase, www electronic publication, National University of Ireland, Galway. http://www. algaebase.org, searched on 27 May 2015.

Howe, M.A. 1918a. Algae. In: (N.L. Britton, ed) Flora of Bermuda. Charles Scribner's Sons, New York. pp. 489-540.

Howe, M.A. 1918b. Further notes on the structural dimorphism of sexual and tetrasporic plants in the genus Galaxaura. Brooklyn Bot. Gard. Mem. 1: 191-197.

Huisman, J.M., J.T. Harper and G.W. Saunders. 2004. Phylogenetic study of the Nemaliales (Rhodophyta,) based on large-subunit ribosomal DNA sequence supports segregation of the Scinaiaceae fam. nov. and the resurrection of Dichotomaria Lamarck. Phycol. Res. 52: 224-234.

Kjellman, F.R. 1900. Om Floridé-släget Galaxaura, dess organografi och systematik. Kgl. Svensk. Vetensk. -Ad. Förhandl., Stockholm 33: 1-109, 20 pls.

Kurihara, A. and J.M. Huisman. 2006. The Dichotomaria marginata assemblage in Australia. In (J.M. Huisman, ed) Algae of Australia, Nemaliales. Australian Biological Resources Study, ABRS, Canberra and CSIRO Publ., Melbourne. pp. 120-122, 134-136.

Kylin, H. 1938. Verzeichnis einiger Rhodophyceen von Südafrika. Acta Univ. Lund. 34: 1-[26], 8 pls. 
Lamarck, J.B.A.P. de. 1816. Histoire naturelle des animaux sans vertèbres... Vol. 2. Paris. Verdière, Libraire, quai des Augustins, 27: pp. 568.

Le Gall, L. and G.W. Saunders. 2010. Establishment of a DNA-barcode library for the Nemaliales (Rhodophyta) from Canada and France uncovers overlooked diversity in the species Nemalion helminthoides (Velley) Batters. Cryptogamie, Algol. 31: 403-421.

Littler, D.S. and M.M. Littler. 2000. Caribbean reef plants. OffShore Graphics Inc., Washington. pp. 542.

Oliveira Filho, E.C. de. 1977. Algas marinhas bentônicas do Brasil. Univ. São Paulo, Instituto Biociências, São Paulo. pp. 407.

Papenfuss, G.F. and Y.-M. Chiang. 1969. Remarks on the taxonomy of Galaxaura (Nemaliales, Chaetangiaceae). Proc. Intl. Seaweed Symp. 6: 303-314.

Papenfuss, G.F., K.E. Mshigeni and Y.-M. Chiang. 1982. Revision of the red algal genus Galaxaura with special reference to the species occurring in the western Indian Ocean. Bot. Mar. 25: 401-444.

Popolizio, T.R., C.W. Schneider, T. Chengsupanimit, G.W. Saunders and C.E. Lane. 2013. Notes on the marine algae of the Bermudas. 13. Helminthocladia kempii sp. nov. (Nemaliales, Liagoraceae) based upon $H$. calvadosii sensu auct. from the western Atlantic. Cryptogamie, Algol. 34: 229-244.

Popolizio, T.R., C.W. Schneider and C.E. Lane. 2015. A molecular evaluation of the Liagoraceae sensu lato (Nemaliales, Rhodophyta) in Bermuda including Liagora nesophila sp. nov. and Yamadaella grassyi sp. nov. J. Phycol. 51: 637-658.

Ronquist, F. and J.P. Huelsenbeck. 2003. MrBayes 3: Bayesian phylogenetic inference under mixed models. Bioinformatics 19: 1572-1574.

Saunders, G.W. and L. Druehl. 1993. Revision of the kelp family Alariaceae and the taxonomic affinities of Lessoniopsis Reinke (Laminariales, Phaeophyta). Hydrobiol. 260/261: 689-697.

Saunders, G.W. and D.C. McDevit. 2012. Methods for DNA barcoding photosynthetic protists emphasizing the macroalgae and diatoms. Meth. Mol. Biol. 858: 207-222.

Schneider, C.W. 2003. An annotated checklist and bibliography of the marine macroalgae of the Bermuda islands. Nova Hedwigia 76: $275-361$.

Schneider, C.W. and C.E. Lane. 2008. Notes on the marine algae of the Bermudas. 9. The genus Botryocladia (Rhodophyta, Rhodymeniaceae), including B. bermudana, B. exquisita and B. flookii spp. nov. Phycologia 47: 614-629.

Silva P.C., P.W. Basson and R.L. Moe. 1996. Catalogue of the benthic marine algae of the Indian Ocean. Univ. Calif. Publ. Bot. 79: (i-xiv) 1-1259.

Silvestro, D. and I. Michalak. 2011 [2012]. raxmlGUI: a graphical front-end for RAxML. Org. Divers. Evol. 12: 335-337.

Taylor, W.R. 1928. The marine algae of Florida, with special reference to the Dry Tortugas. Publ. Carnegie Inst. Wash. 379: [v] + 219 p., 37 pls.

Taylor, W.R. 1960. Marine algae of the eastern tropical and subtropical coasts of the Americas. University of Michigan Press, Ann Arbor. pp. 879.

Wang, W.-L., S.-L. Liu and S.-M. Lin. 2005. Systematics of the calcified genera of the Galaxauraceae (Nemaliales, Rhodophyta) with an emphasis on Taiwan species. J. Phycol. 41: 685-703.
Wiriyadamrikul, J., M.J. Wynne and S.M. Boo. 2014. Phylogenetic relationships of Dichotomaria (Nemalionales, Rhodophyta) with the proposal of Dichotomaria intermedia (R.C.Y. Chou) comb. nov. Bot. Mar. 57: 27-40.

\section{Bionotes}

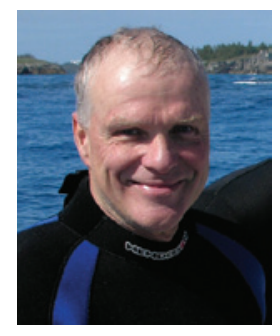

\section{Craig W. Schneider}

Department of Biology, Trinity College, Hartford, CT 06106, USA

cschneid@trincoll.edu

Craig W. Schneider is the Charles A. Dana Professor of Biology at Trinity College in Hartford, CT, USA. He received his PhD under Richard B. Searles at Duke University in 1975. He has extensively studied the floras of the southeastern USA and Bermuda, recently using molecular-assisted alpha taxonomy.

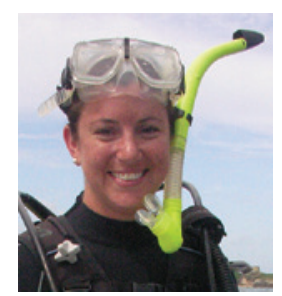

\section{Thea R. Popolizio}

Department of Biological Sciences, University of Rhode Island, Kingston, RI 02881, USA

Thea R. Popolizio received her PhD from the University of Rhode Island in 2015 for her contributions to macroalgal biodiversity studies in the Bermuda Islands. She is presently an adjunct faculty member in the Department of Biology at Salem State University in Salem, MA, USA.

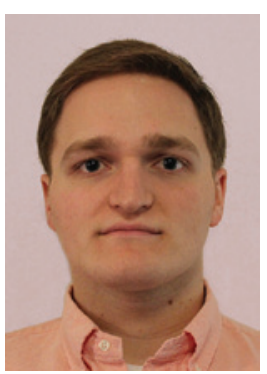

\section{Dylan S. Spagnuolo}

Department of Biology, Trinity College, Hartford, CT 06106, USA

Dylan S. Spagnuolo is an undergraduate Mathematics major at Trinity College, Hartford, CT, USA. His research has focused on the phylogeny of marine algae using both molecular and morphological data. He is currently working with the Digiplante group of École Centrale Paris on mathematical modeling of plant growth. 


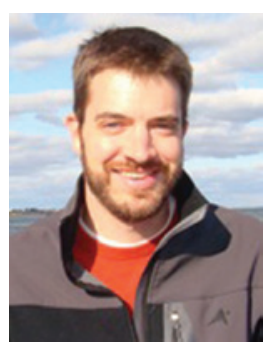

\section{Christopher E. Lane}

Department of Biological Sciences,

University of Rhode Island, Kingston,

RI 02881, USA

Christopher E. Lane received his PhD at the University of New

Brunswick in 2004 for his work in kelp phylogenetics. His lab at

the University of Rhode Island works at the interface of evolution,

phylogenetics and biodiversity at gene to genome-wide scales. 